\title{
Decreased expression of the chemokine CCL21 in human colorectal adenocarcinomas
}

\author{
MELAD MUMTAZ ${ }^{1,3,5}$, DICK WÅGSÄTER ${ }^{2}$, STURE LÖFGREN $^{3}$, ANDERS HUGANDER $^{4}$, \\ NIKLAS ZAR ${ }^{4}$ and JAN DIMBERG ${ }^{5}$ \\ ${ }^{1}$ Biotechnology, Al-Nahrain University, Baghdad, Iraq; ${ }^{2}$ Atherosclerosis Research Unit, Center for Molecular Medicine, \\ Department of Medicine, Karolinska Institute, Stockholm; Departments of ${ }^{3}$ Clinical Microbiology and ${ }^{4}$ Surgery, \\ Ryhov County Hospital; ${ }^{5}$ Natural Science and Biomedicine University College of Health Sciences, \\ SE-551 11 Jönköping, Sweden
}

Received June 27, 2008; Accepted September 30, 2008

DOI: $10.3892 /$ or_00000202

\begin{abstract}
Recent studies have revealed participation of chemokines in cancer by regulating leukocyte movement to modify local immunoresponse. The chemokine CCL21 has been identified to play a pivotal role in homing and localization of immune cells to lymphoid tissue and into organ of nonlymphoid origin. In the cancer biology CCL21 seems to have multifaceted roles. CCL21 attracts CCR7 bearing cells especially $\mathrm{T}$ and dendritic cells but also various cancer cells. Besides the antitumour role as leukocyte recruiting, CCL21 has been shown to facilitate dendritic cell functions and to exert an angiostatic effect. To gain insight into the possible influence of CCL21 on colorectal cancer (CRC) we determined whether the CCL21 is altered in CRC tissue. Collectively, by using ELISA we noted a significant lower CCL21 level in cancer tissue compared with paired normal tissue. Patients with a tumour localized in the rectum revealed significantly lower level of CCL21 than patients with a tumour localized in the colon both compared with paired normal tissue. We used immunohistochemistry and found heterogeneous immunoreactivity predominantly within areas of stromal cells mainly in macrophages. We also used a TaqMan system to investigate two single-nucleotide polymorphisms rs 11574915 and rs 2812377 with supposed effect on CRC. No significant difference was observed between $\mathrm{CRC}$ and control subjects regarding genotype and allelic distributions or associations to clinical characteristics or CCL21 tissue levels. Our study implied that lower level of CCL21 in CRC tissue supports the idea that cancer is related
\end{abstract}

Correspondence to: Dr Jan Dimberg, Department of Natural Science and Biomedicine, University College of Health Sciences, Box 1026, S-551 11 Jönköping, Sweden

E-mail: jan.dimberg@hhj.hj.se

Key words: CC chemokine ligand 21, polymorphism, protein expression, colorectal cancer to immunodeficiency probably depending on regulatory factors produced by tumour cells and that the different levels of CCL21 in rectum and colon may reflect divergent mechanisms in colorectal carcinogenesis. Further studies are needed to clarify whether the CCL21 level has an impact on $\mathrm{CRC}$ progression and survival rate.

\section{Introduction}

Chemokines (chemoattractic cytokines) are secreted proteins, primarily identified as mediators of leukocyte trafficking and homing. In cancer, chemokines play a major antitumourigenic role but have also been shown to participate in tumour growth and tumour progression by angiogenesis, homing of tumour cells to lymph nodes and metastasis to specific organs (1-4). Accumulating evidence point out the implication of chemokines with favorable prognosis in human colorectal cancer (CRC) due to recruiting leucocyte infiltrates (5).

CC chemokine ligand 21 (CCL21)/secondary lymphoid chemokine (SLC) was initially identified to play an important role in homing of immune cells to lymphoid tissue $(6,7)$ but it is also involved in accumulation of lymphocytes into organ and tissue of non-lymphoid origin (8). CCL21 is expressed in high endothelial venules and stromal cells of lymph nodes, T-cell zones of spleen and Peyers patches $(6,9)$. CCR7, the receptor for CCL21 is expressed in naïve T cells, memory $\mathrm{T}$ cells, dendritic cells and natural killer T cells (NKT) $(6,10,11)$. In human, CCR7 has been shown to be expressed in various cancers including epithelial cells of CRC and thought to play an important role in the mechanism of lymph node spread in CRC $(12,13)$. Furthermore, CCR7 has been suggested to mediate inflammatory associated tumour progression in squamous cell carcinoma of the head and neck (14).

Studies reported that CCL21/CCR7 signaling is involved in spreading of tumour cells to lymph node and metastasis to other organ as shown in squamous cell carcinoma of head and neck and breast cancer $(14,15)$. Moreover, CCL21/CCR7 interaction has also been suggested to have a partial influence on lymph node metastasis regarding gastric carcinoma, nonsmall cell lung cancer and melanoma (16-18). On the other 
hand, intratumoural injection of CCL21 has demonstrated an antitumourigenic role of CCL21 in murine pancreatic tumours through recruitment of immune cell infiltrates which reduce the growth of distant tumours as well as treated tumours (19).

Recently, it has been noted that patients who develop colorectal liver metastasis express more CCL21 in their normal liver tissue compared to those with non-malignant liver disorders (20). The same study also observed no markedly higher CCL21 expression in normal liver tissue in comparison with paired normal tissue of esophagus, stomach, pancreas, colon and rectum.

The CCL21 gene is located on chromosome 9 in a cluster with CCL19, CCL27 and IL11RA. Recent studies have identified polymorphisms in chromosome 9 as an interesting target for several diseases $(21,22)$. Several single nucleotide polymorphisms (SNPs) of the CCL21 gene have been identified, ordered into one haploblock. No studies related to CCL21 and CRC have been published. Two of the polymorphisms, the $\mathrm{T}>\mathrm{G}$ conversion in exon 1 (rs 11574915) and $\mathrm{T}>\mathrm{G}$ conversion (rs 2812377) are located in the promoter sequence of the CCL21 gene. However, their functional significance is yet unknown.

Data concerning the expression profile of CCL21 in human CRC are limited. Therefore, we evaluated the protein expression of CCL21 in CRC tissue and examined the relationship of its expression to clinicopathological parameters. Moreover, we screened for CCL21 gene polymorphisms (rs 11574915) and (rs 2812377) to investigate whether they are associated with susceptibility to CRC.

\section{Materials and methods}

Patients and controls. This study comprised blood samples from 262 consecutive patients from southeastern Sweden. The samples were collected when they underwent surgical resections for primary colorectal adenocarcinomas at the Department of Surgery, Ryhov County Hospital, Jönköping, Sweden. Clinicopathological characteristics from the patient were received from surgical and pathological records. The patient group represented 137 males and 125 females with a mean age of 70 years (range: 29-93). The tumours were localized in the colon $(n=134)$ and rectum $(n=128)$ and were classified according to Dukes' classification system: stage A $(n=49), B(n=108), C(n=90)$ and D $(n=15)$. Blood donors $(n=267)$ with no known CRC history and from the same geographical region as the CRC patients were selected as the controls. The control group consisted of 141 males and 126 females with a mean age of 68 years (range: 50-83). All blood samples were centrifuged to separate plasma and blood cells and then stored at $-70^{\circ} \mathrm{C}$.

Tissue samples and lysates. This study utilized tissue samples which were available from 74 of the CRC patients. The tumours and matched normal mucosa used for CCL21 analysis included 42 males and 32 females with the mean age of 67 years (range: 29-83). The tumours were classified according to Dukes' classification system: stage A $(n=14)$, $B(n=27), C(n=22)$ and $D(n=11)$. The tumours were localized in the colon $(n=41)$ and rectum $(n=33)$. Tumour tissue and

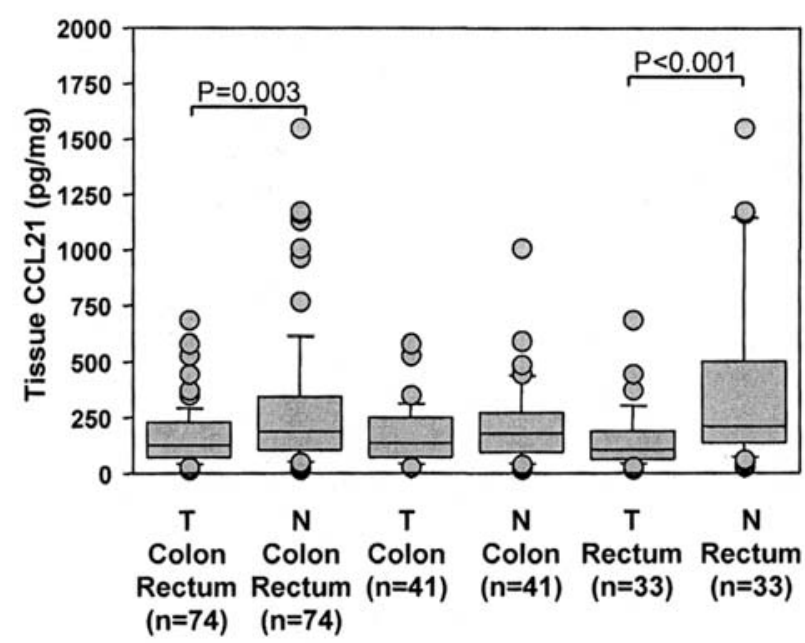

Figure 1. Protein levels of CCL21 in colorectal tissue from 74 colorectal cancer patients. The levels of CCL21 in cancer tissue (T) were compared with paired normal tissue $(\mathrm{N})$.

adjacent normal mucosa ( $\sim 5 \mathrm{~cm}$ from the tumour) from each patient were excised and immediately frozen at $-70^{\circ} \mathrm{C}$ until analysis.

Frozen tumour tissue and normal mucosa were thawed, homogenised in ice cold lysis buffer containing PBS (9.1 mM dibasic sodium phosphate, $1.7 \mathrm{mM}$ monobasic sodium phosphate, $150 \mathrm{mM} \mathrm{NaCl}, \mathrm{pH} 7.4$ ) and $1 \%$ Nonidet P-40, $0.5 \%$ sodium deoxycholate, $0.1 \%$ sodium dodecyl sulphate (SDS), $100 \mathrm{mg} / \mathrm{ml}$ phenylmethylsulphonyl flouride (PMSF), $2 \mathrm{mg} / \mathrm{ml}$ aprotinin, $1 \mathrm{mM}$ sodium orthovanadate and $1 \mathrm{mg} / \mathrm{ml}$ leupeptin . The lysate was placed on ice for $30 \mathrm{~min}$ and then centrifuged at $13,000 \mathrm{x} g$ for $10 \mathrm{~min}$. Protein content of the supernatant fluid was determined for each sample using the Bradford protein assay (Bio-Rad Laboratories, UK).

ELISA of CCL21. CCL21 was measured in tissue using a commercially available enzyme-linked immunosorbent (ELISA) kit (R\&D Systems Europe, UK) following the manufacturer's instructions. The tissue levels of CCL21 from the tumour and paired normal tissue were expressed as picograms per milligram of protein $(\mathrm{pg} / \mathrm{mg})$.

Immunohistochemistry. Fourteen tumour samples were available for immunohistochemical staining to study the cell type origin of CCL21 expression. Staining was performed using a standard protocol on $4 \mu \mathrm{m}$ sections from formalinfixed paraffin-embedded tissue blocks. Antigen retrievel was performed by microwave treatment in citrate buffer ( $\mathrm{pH}$ 6.0). Endogenous peroxidase activity was quenched by treatment with $3 \%$ hydrogen peroxide for $5 \mathrm{~min}$. Sections were subsequently incubated with a primary goat anti-human monoclonal CCL21 antibody (R\&D Systems Europe) in 1:100 dilution for $3 \mathrm{~h}$ at room temperature. After rinsing in tris-buffered saline, sections were incubated with secondary biotinylated antibody; horse anti-goat IgG (Immunkemi, Sweden). Avidin-biotin peroxidase complexes (Dako Cytomation, Denmark) were added followed by visualization with 3,3'-diaminobenzidine tetrahydrochloride (Dako Cytomation). 

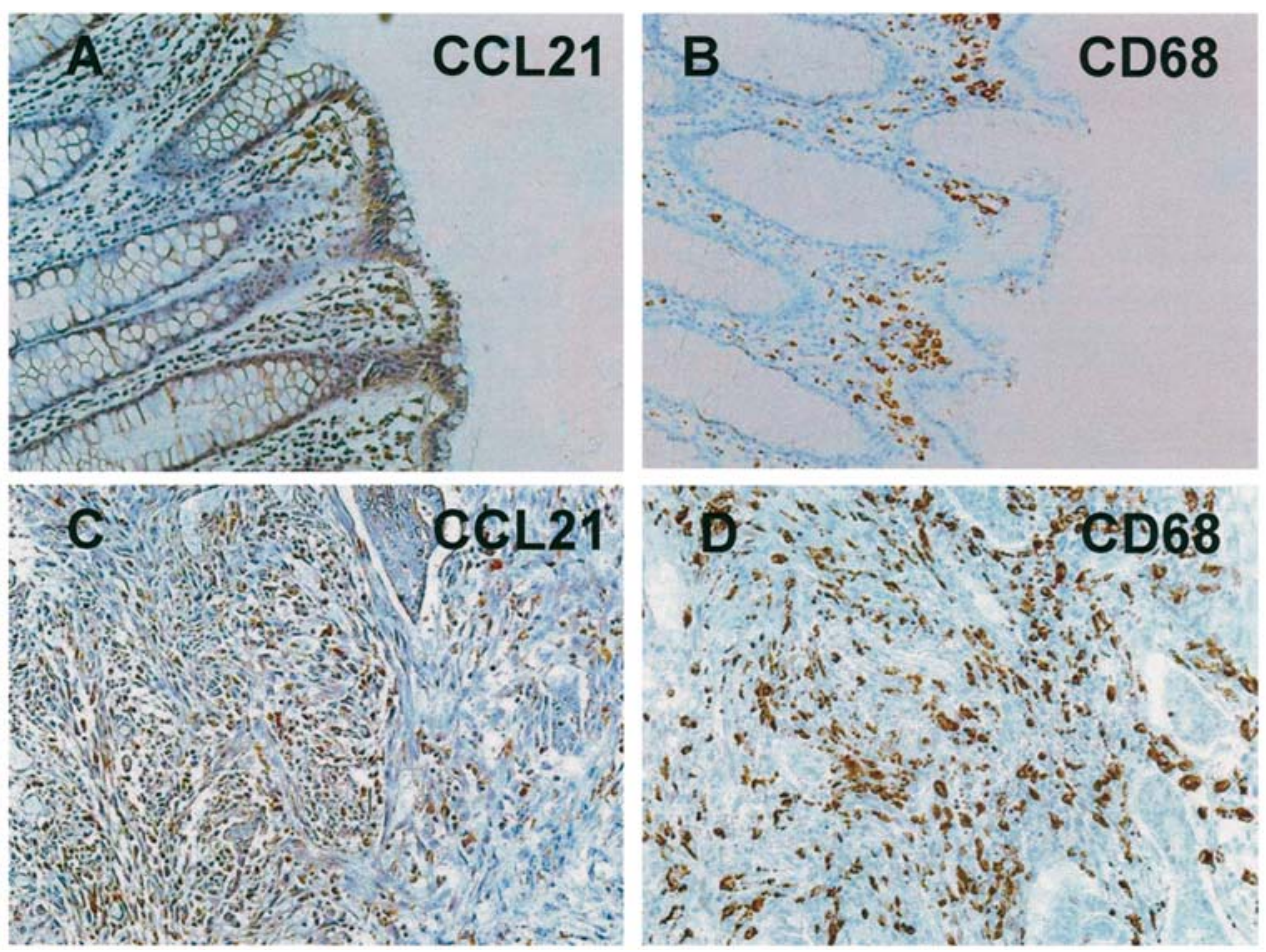

Figure 2. Immunohistochemical detection and localization of CCL21 in colorectal tissue from patients with colorectal cancer. Detection of CCL21 in normal tissue (A) and cancerous tissue (C). Corresponding serial sections (B and D) showing CD68 positive macrophages. Magnification, x200.

All sections were counterstained with Mayer's hematoxylin (Histolab Products, Sweden). As negative controls, the primary antibodies were replaced by an isotype control IgG. Immunohistochemical analyses of adjacent sections with cell type-specific antibody for localization of macrophages were also carried out using mouse monoclonal anti-human CD68 IgG antibody (Dako Cytomation) followed by using EnVision visualization system including avidin-biotin peroxidase complexes and 3,3'-diaminobenzidine tetrahydrochloride (Dako Cytomation). All staining procedures were performed according to the manufacturer's instructions.

CCL21 genotype determination. DNA was isolated from 262 CRC blood samples and 267 donor blood samples using QiaAmp DNA blood kit (Qiagen, USA). DNA samples were genotyped using the 5'-exonuclease allelic discrimination assay (Applied Biosystems, USA). Taqman SNP Genotyping assay was used for analysis of the rs 2812377 ( $T>G)$ and rs $11574915(\mathrm{~T}>\mathrm{G})$ genotypes (Applied Biosystems). DNA (10 ng) was amplified in a total volume of $12 \mu 1$ containing TaqMan Universal PCR master mix (Applied Biosystems) including 1X TaqMan SNP genotyping assay. Amplification was performed using an initial cycle at $95^{\circ} \mathrm{C}$ for $10 \mathrm{~min}$ followed by 40 cycles at $92{ }^{\circ} \mathrm{C}$ for $15 \mathrm{sec}$ and $60{ }^{\circ} \mathrm{C}$ for $1 \mathrm{~min}$. A post PCR endpoint reading was performed on each plate using the 7500 Fast Real-Time PCR system (Applied Biosystems). For rs 11574915 (T>G) 259 of the 262 CRC blood samples were available. The manual calling option in the allelic discrimination application ABI PRISM 7500 SDS software version 1.3.1 was then used to assign genotypes.

Statistical analysis. Differences in the frequencies of the CCL21 gene polymorphisms between CRC patients and the control group and between clinical characteristics within the CRC subgroup were analyzed using the Chi-squared test and the Hardy-Weinberg equilibrium was tested for the genotypes. Differences in CCL21 protein expression between tumour and normal paired tissues were examined by the Wilcoxon's signed rank test. Statistical analyses were performed using SPSS for Windows computer package (Rel. 14.0, SPSS Inc., Chicago: 2005, USA). Results were considered significant at $\mathrm{p}<0.05$.

\section{Results}

Protein levels of CCL21 in colorectal tissue. In order to evaluate the CCL21 protein expression in colorectal cancer tissue and paired normal tissue we measured the concentrations using ELISA in protein lysates from 74 patients. We found a significant difference $(\mathrm{P}=0.003)$ in the levels of CCL21 protein in cancer tissues (median: $123.7 \mathrm{pg} / \mathrm{mg}$; range: $3.8-684 \mathrm{pg} / \mathrm{mg}$ ) in comparison with paired normal tissue (median: $192.0 \mathrm{pg} / \mathrm{mg}$; range: $17.8-1548 \mathrm{pg} / \mathrm{mg}$ ) (Fig. 1). When subdividing the patients into groups of rectum $(n=33)$ and colon $(n=41)$ the evaluation of the relative expression (tumour vs. normal tissue) showed suppression in $79 \%$ $(26 / 33)$ and $54 \%(22 / 41)$ of the subgroups, respectively. The level of CCL21 protein concentration in rectal cancer $(108.2 \mathrm{pg} / \mathrm{mg})$ was significantly lower $(\mathrm{P}<0.001)$ compared with paired normal tissue $(210.2 \mathrm{pg} / \mathrm{mg})$. In the colon cancer subgroup, the CCL21 protein level $(135.7 \mathrm{pg} / \mathrm{mg})$ was not significantly different $(\mathrm{P}=0.176)$ compared with the level in normal paired tissue $(172.0 \mathrm{pg} / \mathrm{mg}$ ) (Fig. 1). There was no association between levels of CCL21 protein and clinical characteristics such as Dukes' stages and gender (data not shown). 
Table I. Genotypic and allelic distributions in \% (n) of CCL21 gene polymorphism (rs 11574915) in CRC patients and controls.

\begin{tabular}{lcccc}
\hline Genotype & $\begin{array}{c}\text { CRC } \\
(\mathrm{n}=259)\end{array}$ & $\begin{array}{c}\text { Controls } \\
(\mathrm{n}=267)\end{array}$ & Allele & $\begin{array}{c}\text { CRC } \\
(\mathrm{n}=518 \text { alleles })\end{array}$ \\
$(\mathrm{n}=534$ alleles $)$ \\
\hline
\end{tabular}

\section{$\mathrm{T} \rightarrow \mathrm{G}$}

\begin{tabular}{lccccc}
$\mathrm{T} / \mathrm{T}$ & $78.4(203)$ & $73.4(196)$ & $\mathrm{T}$ & $88.8(460)$ & $85.8(458)$ \\
$\mathrm{T} / \mathrm{G}$ & $20.8(54)$ & $24.7(66)$ & $\mathrm{G}$ & $11.2(58)$ & $14.2(76)$ \\
$\mathrm{G} / \mathrm{G}$ & $0.8(2)$ & $1.9(5)$ & & & \\
\hline
\end{tabular}

CRC patients vs. controls, not statistically significant.

Table II. Genotypic and allelic distributions in \% (n) of CCL21 gene polymorphism (rs 2812377) in CRC patients and controls.

\begin{tabular}{|c|c|c|c|c|c|}
\hline Genotype & $\begin{array}{c}\text { CRC } \\
(n=262)\end{array}$ & $\begin{array}{l}\text { Controls } \\
(n=267)\end{array}$ & Allele & $\begin{array}{c}\text { CRC } \\
(n=524 \text { alleles })\end{array}$ & $\begin{array}{c}\text { Controls } \\
(\mathrm{n}=534 \text { alleles })\end{array}$ \\
\hline \multicolumn{6}{|l|}{$\mathrm{T} \rightarrow \mathrm{G}$} \\
\hline $\mathrm{T} / \mathrm{T}$ & $42.4(111)$ & $41.2(110)$ & $\mathrm{T}$ & $63.5(333)$ & $62.7(335)$ \\
\hline $\mathrm{T} / \mathrm{G}$ & $42.4(111)$ & $43.1(115)$ & G & 36.5 (191) & 37.3 (199) \\
\hline $\mathrm{G} / \mathrm{G}$ & $15.2(40)$ & $15.7(42)$ & & & \\
\hline
\end{tabular}

CRC patients vs. controls, not statistically significant.

Immunohistochemical staining for CCL21. Sections from CRC specimens were stained to detect localization of CCL21 expression. Immunoreactivity varying from none to weak in epithelial cells of the cancer and at the resection border that reflects normal tissue. However, heterogeneous staining was localized in stromal cells predominantly confined within infiltrate of $\mathrm{CD}^{+} 8^{+}$cells which were identified as macrophages and partly revealed immunoreactivity (Fig. 2). No staining was observed with isotypic IgG antibody which was used as a negative control (data not shown).

CCL21 gene polymorphisms. We used a TaqMan System to ascertain whether an association exists between CCL21 SNPs in CRC patients vs. non CRC subjects and found no significant difference in genotype distribution and in allelic frequencies (Tables I and II). We found 7 combined genotypes and these revealed no significant difference in distribution between CRC patients and the control group (Table III).

When assessing the levels of CCL21 protein in the analysed tissue samples or subdividing the patients in groups of clinicopathological characteristics we were unable to identify any significant difference in genotype or in allelic frequencies (data not shown). Neither the patient nor the control group showed significant deviation from the HardyWeinberg equilibrium.
Table III. Distribution of combined genotypes in \% (n) of CCL21 gene polymorphisms in CRC patients and controls.

\begin{tabular}{lcccc}
\hline $\begin{array}{l}\text { Combined } \\
\text { genotype }\end{array}$ & rs 11574915 & rs 2812377 & $\begin{array}{c}\text { CRC } \\
(\mathrm{n}=259)\end{array}$ & $\begin{array}{c}\text { Controls } \\
(\mathrm{n}=267)\end{array}$ \\
\hline 1 & $\mathrm{~T} / \mathrm{T}$ & $\mathrm{T} / \mathrm{T}$ & $29.3(76)$ & $25.1(67)$ \\
2 & $\mathrm{~T} / \mathrm{T}$ & $\mathrm{T} / \mathrm{G}$ & $33.6(87)$ & $32.9(88)$ \\
3 & $\mathrm{~T} / \mathrm{T}$ & $\mathrm{G} / \mathrm{G}$ & $15.4(40)$ & $15.4(41)$ \\
4 & $\mathrm{~T} / \mathrm{G}$ & $\mathrm{T} / \mathrm{T}$ & $12.4(32)$ & $14.2(38)$ \\
5 & $\mathrm{~T} / \mathrm{G}$ & $\mathrm{T} / \mathrm{G}$ & $8.5(22)$ & $10.1(27)$ \\
6 & $\mathrm{~T} / \mathrm{G}$ & $\mathrm{G} / \mathrm{G}$ & $0.0(0)$ & $0.4(1)$ \\
7 & $\mathrm{G} / \mathrm{G}$ & $\mathrm{T} / \mathrm{T}$ & $0.8(2)$ & $1.9(5)$ \\
\hline
\end{tabular}

CRC patients vs controls, not statistically significant.

\section{Discussion}

Several chemokines and their respective receptors are known to play an important role in the tumour progression (1). CCR7, the receptor for the chemokine CCL21 has been detected in various cancers and has been shown to mediate inflammatory associated tumour progression $(12,14)$. 
To our knowledge little is known about the expression of CCL21 in CRC tissue. In this study, we demonstrated that CCL21 protein level was significantly lower in cancer tissues in comparison with paired normal tissues $(\mathrm{P}=0.003)$. We noted a significantly lower CCL21 level in rectal cancer compared with paired normal tissue $(\mathrm{P}<0.001)$. Moreover, we did not observe a significant difference between the level of CCL21 protein in the colon cancer subgroup and paired normal colon tissue. The difference regarding CCL21 expression in tumours from the rectum and colon may reflect a different mechanism involved in the pathogenesis of cancer in rectum and colon. It has been reported that there may be a different mechanism in the carcinogenesis of CRC based on the tumour location (23). To identify the cellular source and localization of CCL21 we used immnunohistochemistry and found heterogeneous immunoreactivity predominantly within areas of stromal cells mainly in macrophage rich areas. One recent article has showed CCL21 expression both in macrophages and $\mathrm{T}$ cells within atherosclerotic lesions (8). Our findings may confirm that macrophages are capable of CCL21 expression. Moreover, one research group has previously detected CCL21 gene expression in normal colon and rectum (20). Interestingly, transfected CCL21 in breast cancer provides evidence that CCL21 increases antigen presentation and apoptosis resistance of dendritic cells which indicate different antitumour roles for CCL21 (24). In addition, studies have reported that CCL21 exert angiostatic effects in mice $(25,26)$.

One may speculate that the down-regulated CCL21 expression in cancer tissue seen in the current study, probably depends on regulatory factors secreted from tumour cells. This could be a strategy by the tumour to disturb the leukocyte homing and thereby suppress the intestinal immunity. This raises the possibility that elevation of CCL21 levels in CRC tissue could be targeted as the therapy for this cancer.

To date no functional studies have been carried out to elucidate the consequences of the CCL21 gene polymorphisms rs 11574915 and rs 2812377 . We attempted to determine whether an association exists between these gene variants and $\mathrm{CRC}$. We found 7 combined genotypes and the data showed that the genotype distributions and allelic frequencies for the gene variants were not significantly associated with CRC. Furthermore, we investigated whether these SNPs could be potential candidates affecting the expression of CCL21. However, the results showed no correlation (data not shown).

Overall, the present study is a piece of preliminary work looking for the importance of CCL21 levels in colorectal tissue in connection with CRC. Further studies are needed to clarify whether the CCL21 level has impact on CRC progression and survival rate. The screened gene variants of CCL21 seem not to be involved in conferring susceptibility to CRC.

\section{Acknowledgements}

This study was supported by grants from Futurum the Academy of Healthcare, County Council of Jönköping Sweden and the University College of Health Sciences, Jönköping, Sweden.

\section{References}

1. Raman D, Baugher PJ, Thu YM and Richmond A: Role of chemokines in tumor growth. Cancer Lett 256: 137-165, 2007.

2. Balkwill $\mathrm{F}$ and Mantovani A: Inflammation and cancer: back to Virchow? Lancet 357: 539-545, 2001.

3. Ben-Baruch A: The multifaceted roles of chemokines in malignancy. Cancer Metastasis Rev 25: 357-371, 2006.

4. Singh S, Sadanandam A and Singh RK: Chemokines in tumor angiogenesis and metastasis. Cancer Metastasis Rev 26: 453-467, 2007.

5. Ropponen KM, Eskelinen MJ, Lipponen PK, Alhava E and Kosma VM: Prognostic value of tumour-infiltrating lymphocytes (TILs) in colorectal cancer. J Pathol 182: 318-324, 1997.

6. Gunn MD, Tangemann K, Tam C, Cyster JG and Williams LT: A chemokine expressed in lymphoid high endothelial venules promotes the adhesion and chemotaxis of naïve $\mathrm{T}$ lymphocytes. Proc Natl Acad Sci USA 95: 258-263, 1998.

7. Lo JC, Chin RK, Lee Y, Kang HS, Wang Y, Weinstock JV, Banks T, Ware CF, Franzoso G and Fu YX: Differential regulation of CCL21 in Lymphoid/nonlymphoid tissues for effectively attracting $\mathrm{T}$ cells to peripheral tissues. J Clin Invest 112: 1495-1505, 2003

8. Damås JK, Smith C, Oie E, Fevang B, Halvorsen B, Waehre T, Boullier A, Breland U, Yndestad A, Ovchinnikova O, Robertson AL, Sandberg WJ, Kjekshus J, Tasken K, Froland SS, Gullestad L, Hansson GK, Quehenberger O and Aukrust P: Enhanced expression of the homeostatic chemokines CCL19 and CCL21 in clinical and experimental atherosclerosis possible pathogenic role in plaque destabilization. Arterioscler Thromb Vasc Biol 27: 614-620, 2006.

9. Luther SA, Bidgol A, Hargreaves DC, Schmidt A, Xu Y, Paniyadi J, Matloubian M and Cyster JG: Differing activities of homeostatic chemokines CCL19, CCL21 and CXCL12 in lymphocyte and dendritic cell recruitment and lymphoid neogenesis. J Immunol 169: 424-433, 2002.

10. Kim CH, Johnston B and Butcher EC: Trafficking machinery of NKT cells: shared and differential chemokine receptor expression among V $\alpha 24+\beta 11+$ NKT cell subsets with distinct cytokineproducing capacity. Blood 100: 11-16, 2002.

11. Dieu MC, Vanbervliet B, Vicari A, Bridon JM, Oldham E, Yahia SA, Briere F, Zlotnik A, Lebecque S and Caux C: Selective recruitment of immature and mature dendritic cells by distinct chemokines expressed in different anatomic sites. J Exp Med 188: 373-386, 1998.

12. Zlotnik A: Chemokines and cancer. Int J Cancer 119: 2026-2029, 2006.

13. Gunther K, Leier J, Henning G, Dimmler A, Weibbach R, Hohenberger W and Förster R: Prediction of lymph node metastasis in colorectal carcinoma by expression of chemokine receptor CCR7. Int J Cancer 116: 726-733, 2005.

14. Mburu YK, Wang J, Wood MA, Walker WH and Ferris RL: CCR7 mediates inflammation associated tumor progression. Immunol Res 36: 61-72, 2006.

15. Cabioglu N, Yazici MS, Arun B, Broglio KR, Hortobagyi GN, Price JE and Sahin A: CCR7 and CXCR4 as novel biomarkers predicting axillary lymph node metastasis in T1 breast cancer. Clin Cancer Res 11: 5686-5693, 2005.

16. Mashino K, Sadanaga N, Yamaguchi H, Tanaka F, Ohta M, Shibuta K, Inoue $\mathrm{H}$ and Mori M: Expression of chemokine receptor CCR7 is associated with lymph node metastasis of gastric carcinoma. Cancer Res 62: 2937-2941, 2002.

17. Koizumi K, Kozawa Y, Ohashi Y, Nakamura ES, Aozuka Y, Sakurai H, Ichiki K, Doki Y, Misaki T and Saiki I: CCL21 promotes the migration and adhesion of highly lymph node metastatic human non-small cell lung cancer Lu-99 in vitro. Oncol Rep 17: 1511-1516, 2007.

18. Takeuchi H, Fujunoto A, Yamano T, Hsueh E and Hoon DS: CCL21 Chemokine regulates chemokine receptor CCR7 bearing malignant melanoma cells. Clin Cancer Res 10: 2351-2358, 2004.

19. Turnquist HR, Lin X, Ashour AE, Hollingsworth MA, Singh RK, Talmadge JE and Solheim J: CCL21 induces extensive intratumoral immune cell infiltration and specific anti-tumor cellular immunity. Int J Oncol 30: 631-639, 2007.

20. Rubie C, Oliveira V, Kempf K, Wagner M, Tilton B, Rau K, Kruse B, König J and Schilling M: Involvement of chemokine receptor CCR6 in colorectal cancer metastasis. Tumour Biol 27: 166-174, 2006. 
21. Poynter JN, Figueiredo JC, Conti DV, Kennedy K, Gallinger S, Siegmund KD, Casey G, Thibodeau SN, Jenkins MA, Hopper JL, Byrnes GB, Baron JA, Goode EL, Tiirikainen M, Lindor N, Grove J, Newcomb P, Jass J, Young J, Potter JD, Haile RW, Duggan DJ, Le Marchand L and Colon CFR: Variants on 9p24 and 8q24 are associated with risk of colorectal cancer: results from the Colon Cancer Family Registry. Cancer Res 67: 11128-11132, 2007.

22. McPherson R, Pertsemlidis A, Kavaslar N, Stewart A, Roberts R, Cox DR, Hinds DA, Pennacchio LA, Tybjaerg-Hansen A, Folsom AR, Boerwinkle E, Hobbs $\mathrm{HH}$ and Cohen JC: A common allele on chromosome 9 associated with coronary heart disease. Science 316: 1488-1491, 2007.

23. Konishi K, Fujii T, Boku S, Kato I, Ohtsu A, Tajiri H, Ochiai A and Yoshida S: Clinicopathological differences between colonic and rectal carcinomas: are they based on the same mechanism of carcinogenesis? Gut 45: 818-821, 1999.
24. Wu S, Xing W, Peng J, Yuan X, Zhao X, Lei P, Li W, Wang M, Zhu H, Huang B and Shen G: Tumor transfected with CCL21 enhanced reactivity and apoptosis resistance of human monocyte-derived dendritic cells. Immunobiology 213: 417426, 2007.

25. Vicari AP, Ait-Yahia S, Chemin K, Mueller A, Zlotnik A and Caux C: Antitumor effects of the mouse chemokine 6Ckine/ SLC through angiostatic and immunological mechanisms. J Immunol 165: 1992-2000, 2000.

26. Soto H, Wang W, Strieter RM, Copeland NG, Gilbert DJ, Jenkins NA, Hedrick J and Zlotnik A: The CC chemokine 6Ckine binds the CXC chemokine receptor CXCR3. Proc Natl Acad Sci USA 95: 8205-8210, 1998. 